\title{
Do “Interactive” Educational Technologies Promote Interactive Literacy Instruction?
}

\author{
MERIDITH ANN LOVELL-JOHNSTON \\ Lakehead University
}

\begin{abstract}
This article explores the concept of lesson interactivity within six primary and elementary teachers' use of whole-class and personal digital devices over multiple lessons including Interactive Whiteboards, data projectors, laptop computers, and others. The analysis focuses on the differences between technical vs pedagogic interactivity (Smith, Higgins, Wall, \& Miller, 2005) where technical interactivity refers to direct tactile interaction with technology and pedagogic interactivity refers to the interaction between teachers, students, and lesson content which may occur with or without technology use. Technical interactivity varied in duration between teachers and lessons, but teachers' use of whole-class devices typically exceeded students' use. Use of personal devices by students was infrequent, and often supported the content displayed on a whole-class device. In terms of pedagogic interactivity facilitated by technology use, the most frequent activities were teacherdirected questioning and guided practice, during which the teachers had a correct answer or method in mind. Use of deeper pedagogic interaction through discussion, student inquiry, or research were not observed. Teachers expressed that they faced barriers to interactive technology use including program and resource constraints as well as lack of teacher comfort with technology.

This research was conducted following Tri-Council guidelines for the Ethical Conduct of Research Involving Humans. It has passed the research ethics board of two universities and two school districts.
\end{abstract}

\section{Introduction}

Technology integration in education is mandated by programs of study in Canada and in many other places around the world. Advocates of technology integration extol improved student achievement (Butzin, 2001), heightened motivation and engagement (Cheng, 2017; Norris, Sullivan, Poirot, \& Solloway, 2003; Passey, Rogers, Machell, McHugh, \& Allaway, 2003), and performance in curricular areas such as in Language Arts (e.g., Andresen, 2017; Curcic \& Johnstone, 2016; Lopez, 2010; Maher, 2011). Canadian research has also reported similar perceived benefits to students' learning and teachers' instruction (Froese-Germain, Reil, \& McGahey, 2013); however, the presence of technology neither ensures it is integrated effectively nor used to promote pedagogically appropriate practices (Bauer \& Kenton, 2005; Hooper \& Rieber, 1999) and new technologies are often used to replicate traditional delivery methods such as blackboards (Beauchamp, 2004; Serow \& Callingham, 2011) or drill-and-practice worksheets (Franklin, 2007). There are significant gaps and inconsistencies in the literature regarding technology use in literacy education and particularly how the educational experience differs from traditional instruction, what types of resources teachers use to support literacy instruction with technology in the early grades, and whether technology resources are 
instructionally supportive and pedagogically appropriate. For example, Mohon (2008) criticized research about the use of educational technologies for failing to critically analyze use of the technologies under study.

In this article, I examine the concept of interactivity of teachers' use of whole-class devices, personal digital devices, and no technology from a pedagogical perspective. Interactivity is frequently reported as a benefit of technology use in education, especially with whole-class technologies such as Interactive Whiteboards (de Koster, Volman, \& Kuiper, 2013; Haldane, 2007), yet researchers and manufacturers who make these claims often fail to define what is meant by interactivity or how it is measured (Lovell \& Phillips, 2012) and ignore limitations to the hardware such as slowing of lesson pacing (Mohon, 2008) and enabling fewer students to interact with the hardware (Quashie, 2009).

In order to analyze how teachers used various types of technology in their instruction and how this might contribute to 'interactivity', the purpose of this study was to:

1. Document and analyze teachers' use of (a) no technology, (b) whole-class devices only, (c) personal digital devices, or (d) mixed use of whole-class and personal digital devices over time as part of classroom instruction;

2. Analyze (a) the pedagogical purposes for which devices were used, (b) similarities or differences in how they were used, and (c) whether use promoted technical, vicarious, or pedagogic interactivity (Quashie, 2009; Smith, Higgins, Wall, \& Miller, 2005) in lessons; and

3. Elicit teachers' perceptions about the benefits of technology use for instruction and, particularly, for interactivity.

For comparison purposes, this article combines previously unpublished data from an earlier study of primary (grades K-3; Study 1) teachers' use of Interactive Whiteboards (IWBs) to teach reading in their language arts classes to newer data centering on elementary (grades 4-6; Study 2) teachers' use of whole class and personal devices in language arts and other subject areas.

\section{Background}

The prevalence and variety of digital technology and multimedia resources in classrooms is increasing. For example, sales statistics show millions of North American classrooms have access to at least two technological platforms, an Interactive Whiteboard (IWB) and a personal or laptop computer (SMART Technologies, 2015). Although the initial trend was to use whole-class devices such as IWBs or projectors, additional personal digital devices such as netbooks, tablets (like iPads), and smartphones are now frequently used to support instruction as well. Studies of technology use in education have followed suit, progressing from computer use, to whole-class technologies such as IWBs that promised to improve visibility and interactivity of technology use while requiring less hardware to be purchased, to the current trend towards individual devices such as one-toone laptop initiatives, tablets, and smartphones.

Researchers of pedagogical change have focused on the perceived increase in lesson interactivity afforded by IWB and other technology use (de Koster et al., 2013; Gray, Hagger-Vaughan, Pilkington, \& Tomkins, 2005; Haldane, 2007; Quashie, 2009). Yet, despite reports of increased interaction in promotional literature, support from case studies is mixed (Lovell \& Phillips, 2012) with some reporting increased interaction (i.e., Haldane, 
2007), some reporting decreased interaction (i.e., Mohon, 2008), and some reporting mixed results (i.e., Quashie, 2009). Across these studies and others, researchers rarely report criteria used to determine whether and how teaching is interactive or the duration of interactive activities in comparison to perceived non-interactive studies. Researchers seldom describe what conditions are like when the technology is not in use so that comparisons can be made between interactivity with and without technology use. And, most importantly, the term interactive is used inconsistently between studies and is rarely defined (Lovell \& Phillips, 2012; Smith et al., 2005). For example, in the case of wholeclass technologies such as IWBs, at times it is used to refer to the capacity to respond to touch - hence the title Interactive Whiteboard (Saddler Jones, 2012), to students' tactile interaction with the IWB (such as in Mohon, 2008), and to interaction between and amongst teachers, students, and lesson content (such as in Haldane, 2007).

Smith et al. (2005) used the term technical interactivity to refer to the capacity for tactile interaction with an IWB and the term pedagogic interactivity to refer to pupils' general participation in whole-class interactions (surface activities) and to reciprocal acts of communication (deep activities). In using the term pedagogy or pedagogic, I refer to Hirst (1973) and Olson's (2010) robust description of teaching act as beginning with a focus on a goal or outcome in mind and focusing on intentional actions by both teachers and students to achieve the outcome. Thus, in terms of IWB use, pedagogic interactivity would refer to the capacity to facilitate interaction between and amongst teachers, students, and lesson content to varying degrees. These terms add a helpful level of specificity to the term interactivity and are applicable to other types of educational technology as well. I use these terms to differentiate between the tactile interaction between students and the hardware (technical) and the potential to facilitate interaction between people and ideas that would include an exchange of ideas by conversation or questioning (pedagogic). Additionally, Quashie (2009) used the term vicarious interaction to describe incidences where students did not have direct tactile contact with the whole-class technology, but instead directed another student or the teacher to perform actions on the device based on verbal or non-verbal feedback from the group.

Technical interactivity. One advantage of digital devices over static media such as whiteboards, chart paper, or books is the potential afforded to interact with elements on the screen and to have them move in response to this tactile interaction. In order for elements to move on a static medium, they must be erased and redrawn or rewritten. Additionally, in comparison to a personal computer, the display on whole-class devices such as IWBs is larger and is visible to more students. Touch-sensitive whole-class devices enable students to interact with the use of their fingers, similar to other touch-sensitive media like smartphones and tablets which are familiar to many children.

Most studies of interactivity with touch-sensitive whole-class devices such as the IWB describe interactivity from a purely technical standpoint. These studies typically describe instances where students come to the IWB and interact with screen elements (for example, Haldane, 2007). Yet, despite the advantages of and potential for student interaction with the IWB, not all interaction with the IWB is technical. Many whole-class devices accept input from one point of contact (touch by finger or pen) at a time. So, when one student is at the IWB, others are seated at their desks. In order for these students to be part of the activity at the IWB, many teachers, including ones Haldane observed, have 
students interact vicariously by verbally directing the actions of their peer or teacher at the IWB. Haldane described these 'interactive events' but, interestingly, these interactive events lasted for a maximum of four minutes.

Technical interaction can be time-consuming when all students are afforded the opportunity for meaningful interaction with touch-sensitive technologies such as the IWB. With a traditional static whiteboard, multiple students can write on the board at once, yet with an IWB, this is often not possible. In a classroom with many students, the failure to recognize multiple touches can be problematic. For example, Mohon (2008) initially provided many opportunities for students to interact with the IWB but, over time, found lesson pacing slowed considerably and she began to offer fewer opportunities for students' tactile interaction. As many classrooms in the schools where these studies were performed move towards data projectors instead of IWBs, there is little technical interaction with the whole-class content by students except through the dedicated classroom computer. In terms of personal device use, there is potential for increased technical interactivity over wholeclass devices because students interact with the devices. Yet, this increase in technical interactivity assumes all students have access to a device, whether a class set of netbooks or iPads (that is often shared among several classes) or students' own devices.

Pedagogic interactivity. Although the potential for technical interactivity afforded by technology use in education is unquestioned, even if, in practice, technical interactivity may lead to problems with lesson pacing for whole-class devices or adequate access to devices for personal digital devices, it is the potential for pedagogic interactivity that is more important and relevant to the consideration of technology use in the classroom from a pedagogical perspective. If educational technology use, even highly technically interactive use, does not contribute to learning, then the device is not an effective tool for education. One advantage claimed for whole-class devices like the IWB over static media is that teachers and students are able to research and access information on the Internet to aid discussion and enhance understanding. Visuals, animations, sound, and video can help students to understand lesson content in a way they may not be able to understand through print alone (Leu, Coiro, Castek, Hartmann, Henry, \& Reinking, 2008; Leu, Kinzer, Coiro, \& Cammack, 2004).

Unfortunately, most studies of technology use in the classroom do not address pedagogic interactivity directly. Researchers such as Haldane (2007) relate examples of 'interactive events', or times when students verbally directed the actions of a peer or teacher at the IWB. Quashie (2009) referred to these types of interactions as vicarious. These vicarious interactions were described in mainly technical, not pedagogic, terms because researchers rarely discussed whether or how the interaction between the students (giving directions and feedback) facilitated improved understanding or teaching of content. Although not framed as pedagogic interactions, Quashie (2009) did describe instances where interactions occurred through discussion or questioning between teachers and students, although the quality of that interaction ranged from a non-verbal 'thumbs up' gesture to show agreement to actual discussion. During these interactions, typically one student or the teacher was at the IWB. When interviewed, teachers and students gave positive reactions about the interactivity in the lessons, but mixed reactions about whether the IWB or teachers' pedagogic choices was more responsible for the interactivity. As one teacher mentioned, traditional media ('chalk and talk', Quashie, p. 36) would have had a 
similar outcome in terms of interactivity.

Hennessy, Deaney, Ruthven, and Winterbottom (2007) described a disturbing trend of teachers to limit pedagogic interaction through 'funneling'. As mentioned previously, whole-class and digital devices facilitate access to information on the Internet. But, rather than using the Internet to access information on topics of choice and pursue inquiry, many teachers ask close-ended questions with a specific intended response. For example, through the use of an IWB such as a SMART Board, teachers often have access to manufacturerand teacher-created resources such as SMART Exchange which has many premade resources such as passages with comprehension questions. In this way, the IWB may be used as a digital worksheet, not a tool to research or facilitate discussion.

\section{Theoretical Framework}

Teaching and learning are maximized when a clear goal for instruction is established and both the teacher and students make intentional actions to meet the goal (Hirst, 1973; Olson, 2010). Thus, the actions and objectives of the teacher to bring about learning are crucial. Technology can be used as a tool to assist with instruction, but it cannot be seen to teach, because it lacks the capacity for intentionality and to effectively respond to and anticipate individual students' needs. Instead, effective teachers balance technology use with their pedagogy and content area knowledge (Mishra \& Koehler, 2006), a model termed Technology, Pedagogy, and Content Knowledge (TPCK), to plan instruction that utilizes the affordances of the technology to support learning in their specific contexts. When these concerns are not balanced, sometimes technology is promoted without consideration of pedagogical appropriateness (Bauer \& Kenton, 2005) or is used to replicate existing teaching practices without regard for its unique, supportive features (Beauchamp, 2004).

\section{Materials and Methods}

This article draws on data from two studies of teachers' pedagogy and educational device use. Primary data collection involved classroom observation of lessons taught by teachers (eight lessons each by 4 teachers in Study 1 and 4 lessons each by 2 teachers in Study 2) over 4 to 6 months. In total, there were 35.2 hours of observation for Study 1 and 11.4 hours of observation in Study 2. Each observation had a follow-up semi-structured interview of no more than 20-30 minutes to debrief the lesson and discuss participants' perceptions of pedagogy and pedagogical change with technology use. Study 2 arose out of questions generated from Study 1 including whether teachers with older students who are already proficient readers might use educational technologies differently than teachers of early readers in order to facilitate pedagogically interactive activities and whether there were pedagogical differences between teachers' interactive use of whole-class devices and personal digital devices in their classrooms.

\section{Study 1}

Four participants were drawn from teachers in a lead school for technology integration in a large urban school district in Western Canada. Selection criteria were that teachers taught in mainstream classrooms and integrated technology into at least half of their language arts lessons each week. Participants taught in either the regular program or in an enhanced program that places pedagogical focus on teacher-directed, whole-class 
instruction with extensive individual practice. Participants' experience with the IWB ranged from 1.5 to 4 years. Kathleen, a Kindergarten teacher with 27 years of experience; Krystele, a Kindergarten teacher with 12 years of experience; and Therese, a third grade teacher with 3 years of experience had each been using the IWB for approximately 1.5 years. Olivia, a first grade teacher with 13 years of experience, had been using the IWB for approximately 4 years. (All names are pseudonyms). All participants received initial training in IWB use at their current teaching placement.

Although the focus of Study 1 was on IWB use, teachers used a variety of wholeclass and personal digital devices such as document cameras, clickers, and netbook computers. Participants' classrooms were observed for eight sessions each (range 21 to 85 minutes in length) over a four-month period (November until February). IWB lessons were recorded with Camtasia Studio 7 (TechSmith, 2010), a screen capture program. All lessons and interviews were audio-recorded and participants provided copies of electronic lesson files and paper resources used during the lessons.

\section{Study 2}

Participants were drawn from a geographically diverse school district in Central Canada that has an instructional focus on technology integration. Selection criteria were that teachers frequently used either whole-class or personal digital devices in their classrooms or a mixture and taught in the elementary grades (grades 4-6). Two teachers consented to participate: Casey, a special education teacher with students from grade 4 to 8 , and Sharon, a sixth grade teacher in a mainstream classroom. (Names are pseudonyms). Both participants self-identified as proficient technology users. Many of Casey's students were also students in Sharon's classroom; however, all observations of Sharon's class occurred during pull-out time in the mornings.

In terms of technology available within the classroom, Casey and Sharon both had classroom laptop computers attached to projectors, although Casey also had an IWB which was only functional in later observations because there had been an issue with installing the mounted camera and she used a projector on a mobile cart. Both also utilized teacher laptops (Chromebooks) issued by the school. At times when she was having technical issues, Sharon would switch between the computers and attach one or the other to her projector. Sharon also made use of a CD player and document camera. For personal devices, all students in Casey's class were assigned individual notebook computers in their individual program plans. They used various supportive software and devices such as Kurzweil, a text to speech program that reads print to students as they work, and headphones. Students in Sharon's class were not assigned one-to-one laptops; however, students were observed to use some netbooks during class, as well as iPads and calculators on occasion.

Participants' lessons were observed for 4 sessions each between January and June. Most lessons were language arts lessons, although mathematics, social studies, and science lessons were also observed. Observed lessons ranged from 46-100 minutes, with 100 minutes being typical.

Data Analysis

Interview transcripts. Interview transcriptions were assigned keyword codes 
relating to interactivity, technology use or non-use, and literacy or content-area instruction. An initial set of themes for codes were developed at the beginning of the study: benefits of technology use, drawbacks of technology use, literacy instruction techniques, and technology use/non-use. In terms of potential benefits of technology use, I had developed an initial subset of codes based on reported benefits in research literature as well as manufacturers' promotional materials (Lovell, 2014). These included interaction/ interactive/ interactivity, motivation/motivational/ fun/ enjoyment, engaging/ engagement, improved learning, and pedagogy/ instructional change because these claims were often repeated in the research and promotional literature in various ways, despite being vaguely defined (Lovell \& Phillips, 2012). From an initial common pool of semi-structured interview questions to establish demographic information and background with technology use, as well as general stance towards technology use in instruction, questioning over the weeks evolved to include explanations of incidents that occurred during observations, analysis of perceived benefits and drawbacks of technology use, and other topics of interest. Sometimes, one participant would answer a question in a way that was then brought into others' interviews, such as when one teacher responded that using the IWB was "engaging". When prompted to explain how she knew that IWB use was "engaging" students cognitively, the teacher stated that she had never thought about it that way. The next week, the other participants were asked similar questions about engagement as well. Throughout the course of the interviews, the initial themes were narrowed somewhat and other temporary codes were added based on individual teachers' responses. In the end, the initial codes for benefits of technology use were the most utilized topics of conversation across all teachers. Interestingly, many benefits advanced by the teachers, such as interactivity and engagement, were identical to those claimed in the promotional literature. Interactivity was the most frequently discussed benefit to pedagogy advanced by the teachers in Study 1, and thus, became a specific focus for Study 2. Specific codes related to interactivity for interview data are included in Appendix 1, along with examples from participants' responses.

Interview transcripts were broken into excerpts, meaning a block of words that explained a common topic or incident. A simple "find" search was used for each of the key word codes as well as a secondary read-through to find instances where the exact key word might not have been used. The key word and the contextual text around it was moved to a secondary document where each was categorized as positive/beneficial, negative/barrier, or mixed. Examples of positive or beneficial episodes might be where the teacher stated the technology made her lesson more interactive (vague), or that the students had interacted with the technology in a beneficial way, or that learning was improved by the interaction. Negative episodes included discussions of barriers to interactivity such as technical problems, slowed lesson pacing, limitations of the technology, or examples of where a student did not enjoy or feel confident using the technology. Mixed examples were either neutral, such as discussion of having used the interactive features of the technology without indicating benefit, or where both positive and negative aspects of the technology use were discussed at the same time.

Observation transcripts. Observation transcripts were coded for technology use or non-use and by interaction type (i.e., by teacher or student; device type). The full transcript of each lesson was coded line-by-line for technology use/non-use and by whom (teacher, 
student, or both) in the initial reading. The duration of the technical interactivity was confirmed through reviewing timestamps on Camtasia generated videos where applicable. From this initial coding, transcripts were divided into discrete activities (such as morning routine, read-aloud, or comic-making activity) for analysis. These activities were assigned instructional activity codes based on one or more of Dewitz, Jones, and Leahy's (2009) categories of teaching activities by examining the purpose or actions of the teacher and students at each part of the activity (i.e., modeling, guided practice, questioning, information transmission, independent practice, etc.). These codes were later collapsed to (1) teacher-only, (2) student-only, and (3) teacher + student activities. Examples of the activity codes and collapsed activity codes with exemplars are included in Appendix 2. Descriptive statistics were used to determine frequency and duration of device use by type and of interaction by the teacher and students. The frequency and type of interaction with the devices were used to support or challenge statements made by participants about the frequency of interaction with technology in their classrooms. Excerpts from coded lesson summary protocols for each study are included as Appendix 3 (from Study 1) and Appendix 4 (from Study 2).

Technical interactivity. Types of technical interaction observed in the lessons were coded in order of decreasing tactile interactivity for each device type. First, the degree of physical interaction was considered and then whether the teacher or students had interaction with the hardware. Several categories emerged for direct technical (tactile) interactivity with devices: teachers', students' (independent), and students' (directed by the teacher). Codes related to single or few students' interaction vs many or all students' interaction were added. Three categories emerged in which neither the teacher nor students had tactile interaction with the devices: such as when the teacher and students read information displayed on or with help of the device (display only), mentioned the device during a transition (mentioned), or did not actively use the device, which included times when the device was switched off or when it was on but not used for that part of the lesson (not used). Time stamps on the transcripts and Camtasia output were used to determine the duration of each interaction type (technical or no interaction) by person (teacher or student) and device type (whole-class or personal device). A tally was also kept of how many students had technical interaction with each type of device for each lesson.

Pedagogic interactivity. Observation transcripts were recoded from the Dewitz et al. (2009) categories and divided into teacher-only, student-only, and teacher+student activities (similar to Northcote, McQuillan, \& Beamish, 2012). Teacher-only activities included teacher modeling and information provision activities like reading to students. Student-only activities included independent practice and small group-activities where the teacher was not directing. Teacher+student activities included guided practice, discussion, and question/response activities. Unlike technical interactivity, for which device use is prerequisite, pedagogic interactivity can occur with or without device use. Thus, a comparison of interactivity with and without each type of device was possible. Time stamps on transcripts were used to determine the duration of each activity type (teacher-only, studentonly, teacher+student) and which type of device was used. 
Teacher participants were observed for several lessons each over an extended period in order to understand whether the practices observed were typical for the teacher. In Study 1, observed lessons varied in length from 21 to 85 minutes (mean 64 minutes), for a total of 35.2 hours of observation in total. Teachers indicated in their interviews that they used the IWB 'all the time' during their teaching. With a brief exception by Krystele who switched off her IWB during centers time in one class period or when dealing with technical glitches, the IWB was switched on for the entirety of every lesson observed (32 in total). Yet, there were times the IWB sat idle; that is, it was not watched, touched, or mentioned. So, even though the IWB was switched on, it was not in active use. In addition to the IWB, Olivia's students used clickers for entering individual responses to quizzes (personal devices) and Therese's students used netbook computers on two occasions to create online comic strips and to compose personal letters. In Study 2, observed lessons varied from 46 to 100 minutes, although most were 100 minutes, for a total of 11.4 hours of observation in total. Teachers used a variety of devices, but tended to switch off devices when not in active use. Table 1 presents a summary of the total duration of observation for 8 class periods (Study 1) and 4 class periods (Study 2) each. To facilitate comparison, duration values for technology use and for each type of device are presented as percentage of total observed time for each teacher, since the total observed time varied considerably.

Table 1

Duration of Observed Lessons and Percentage Duration of Technology Use by Type

\begin{tabular}{|c|c|c|c|c|c|c|}
\hline & \multicolumn{4}{|c|}{ Study $1(\mathrm{~K}-3)$} & \multicolumn{2}{|c|}{ Study 2 (4-6) } \\
\hline & Kathleen & Krystele & Olivia & Therese & Casey & Sharon \\
\hline $\begin{array}{l}\text { Total } \\
\text { Observation }\end{array}$ & $409 \min$. & $540 \mathrm{~min}$. & 656 min. & $448 \min$. & 400 min. & $281 \mathrm{~min}$. \\
\hline Tech Use (\%) & $43 \%$ & $48 \%$ & $54 \%$ & $66 \%$ & $73 \%$ & $37 \%$ \\
\hline$W C D^{*}$ Only & $(43 \%)$ & $(48 \%)$ & $(49 \%)$ & $(56 \%)$ & $(38 \%)$ & $(22 \%)$ \\
\hline$P D D^{*}$ Only & $(0 \%)$ & $(0 \%)$ & $(0 \%)$ & $(10 \%)$ & $(35 \%)$ & $(9 \%)$ \\
\hline$W C D \& P D D$ & $(0 \%)$ & $(0 \%)$ & $(5 \%)$ & $(0 \%)$ & $(16 \%)$ & $(6 \%)$ \\
\hline No Tech Use (\%) & $57 \%$ & $52 \%$ & $46 \%$ & $34 \%$ & $27 \%$ & $63 \%$ \\
\hline
\end{tabular}

Note. Whole-Class Device use (WCD); Personal Digital Device use (PDD). No Tech Use refers to times when devices are turned off or are turned on but are not being used in the lesson.

The duration of technology use varied greatly across teachers and across individual lessons for each teacher. In Study 1 with primary teachers, each participant expressed the perception that she used the IWB 'all the time'. Yet, the main technologies used by these teachers, specifically the IWB for Kathleen, Krystele, and Olivia and the document camera for Therese, were in active use for $51 \%$ of observed time overall. Kathleen and Krystele were just under $50 \%$ and Olivia and Therese were just over $50 \%$ of lesson time, although not all activities where the IWB or document camera was used were directly linked to lesson objectives, such as activity breaks and morning routines. When activities without clear instructional objectives to teach new content were removed (Hirst, 1973), the whole- 
class devices were used for $56.0 \%$ of total instructional time with Kathleen just under $50 \%$ and the others between $54 \%$ and $60 \%$. Observation of personal digital device use was not a focus of Study 1, although Olivia used clickers in conjunction with the IWB to administer a quiz during one lesson and Therese had students use netbooks to write independently during two lessons. In discussion with the participants, key factors that participants perceived as influencing their technology use in class were instructional program (i.e., specific pedagogies promoted or restricted in each program were deemed more or less suitable for technology use), availability of resources (such as having a class set of clickers available, needing to sign out a netbook cart, or waiting on repairs to the IWB), and participants' confidence with technology use.

In initial conversations with the school administrator and the lead teacher (who was the teacher-librarian for the school) prior to data collection, both had remarked that teachers who taught in the enhanced academic program (i.e., the program in which Kathleen and Olivia taught) typically viewed educational technology to be incompatible with the traditional teacher-directed, whole group instructional model required, but that this view was changing. The required pedagogical model in this program focused on rote memorization and frequent written assessments in an enriched curriculum that exceeded the academic requirements of the provincially mandated curriculum. Both teachers used the IWB to display content, model required skills, and question students. Even Krystele and Therese, who had more pedagogical flexibility in their programs, frequently used the IWB to reinforce skills using teacher-directed tasks, although they did utilize group work (Therese), centers, and free play (Krystele). However, the IWB was utilized only to support teacher-directed activities (Therese) or to practice using sites the teacher had already modelled in class (Krystele). Rather than instructional program or pedagogical decisionmaking, it appeared that the last factor, confidence with technology use, appeared to be particularly evident in whether, how often, and what type of opportunities for technical interactivity were made available to students, which will be addressed in the next section.

In Study 2 with elementary teachers, the contrast in duration and type of device use between the two teachers is striking. Casey used devices for nearly three quarters of observed time and Sharon for approximately one third. Although both professed comfort with technology use and made opportunities for interesting activities with technology, such as when Sharon's class performed science experiments about seed germination while referencing a NASA website or when Casey's students used netbooks to make posters of themselves illustrating different sentence structures, there were factors that appeared to influence the duration and type of use. As with Study 1, instructional program was a key pedagogical consideration, but for Study 2 participants, it also affected availability of resources. For example, Casey's students were assigned netbooks that followed them between classes, whether that was their homeroom or Casey's class, so all students had access to personal devices, which was not the case for Sharon's students who shared access to class devices. Additionally, as part of their program accommodations, Casey's students frequently accessed software such as Kurzweil (which reads text aloud to students) to support their reading. An unanticipated barrier to Casey's use of technology was that a number of students disliked using technology in class, associating it with work and challenge rather than pleasurable pastimes such as their gaming pursuits at home. Type of activity also appeared to be a determining factor in whether and how these teachers used technology. For example, Sharon's students participated in an ongoing simulation of world 
governments and diplomacy for which she had constructed a large game board. All simulation resources and activities were paper-based and hands-on, although a few students did use iPads or calculators to support researching prices or making calculations. For Sharon, a final barrier was that although she had planned to use specific websites during several of the observed lessons, computer or Internet issues caused her to change the activity to remove technology use entirely or spend much instructional time trying to fix technical issues.

When this study was planned, one anticipated difference from Study 1 was the possibility of seeing whether teachers of students who were approaching full fluency might use the interactive and communicative properties of the IWB to support student-led inquiries, research, or communication with people outside the classroom via the Internet. These activities would more closely replicate or support the ways technology is used in society. Yet, although Sharon's pedagogy often emphasized hands-on, inquiry-based learning, such as in the world game simulation, technology was not a major support for these activities. Instead, the projector was used to present problems and read content. Casey's remedial class, on the other hand, had a more traditional teacher-directed pedagogy that focused on building the foundations of literacy through whole class activities such as shared reading with the teacher and workbook completion. Students had more access to individual devices, but these devices were often used more for accommodations purposes (i.e., Kurzweil) or to present content to be learned, and not for more student-directed pursuits.

\section{Technical Interactivity}

The patterns of technology use and non-use have implications for interactivity and interaction. If technology is not in active use, for example, then there can be no technical interaction by students. Time stamps on observational transcripts were used to determine the duration of technical interactivity with whole class devices and personal devices during the entire lesson for each observation, but not limited to activities that meet Hirst's (1973) definition of instructional activities, that is, where the purpose is to teach new content. Table 2 provides a summary of the duration of technical or non-interaction (static display only) with the whole-class devices and personal digital devices by teachers and students that occurred during technology-use portions of eight observed lessons per teacher for Study 1 and four observed lessons per teacher for Study 2.

Table 2

Percentage Duration of Technical Interactivity by Teacher and Students by Device Type

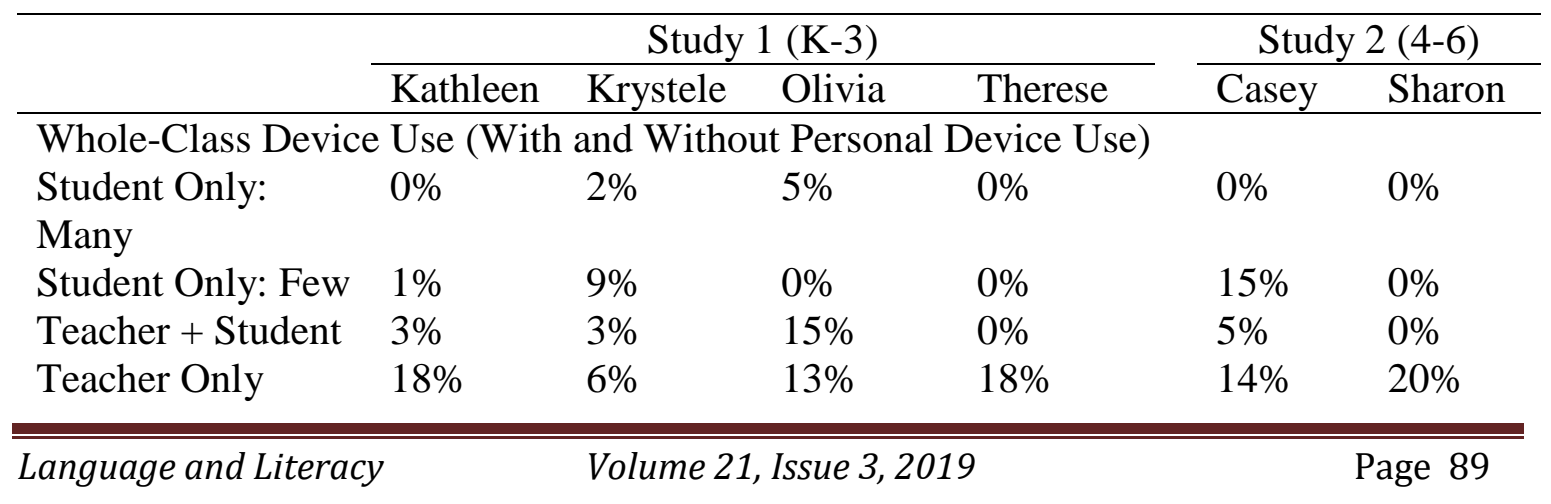




\begin{tabular}{lcccccc} 
Display Content & $16 \%$ & $25 \%$ & $20 \%$ & $37 \%$ & $5 \%$ & $8 \%$ \\
Off or No Use & $61 \%$ & $55 \%$ & $47 \%$ & $45 \%$ & $62 \%$ & $71 \%$ \\
\hline $\begin{array}{l}\text { Personal Device Use (With and Without } \\
\text { Student Only: }\end{array}$ & n/a & nhole-Class & Device Use) & & \\
Many & & & $0 \%$ & $9 \%$ & $36 \%$ & $6 \%$ \\
Student Only: Few & n/a & n/a & $0 \%$ & $0 \%$ & $5 \%$ & $9 \%$ \\
Teacher + Student & n/a & n/a & $4 \%$ & $1 \%$ & $2 \%$ & $0 \%$ \\
Teacher Only & n/a & n/a & $0 \%$ & $0 \%$ & $7 \%$ & $0 \%$ \\
Display Content & n/a & n/a & $1 \%$ & $0 \%$ & $2 \%$ & $0 \%$ \\
Off or No Use & n/a & n/a & $95 \%$ & $90 \%$ & $49 \%$ & $85 \%$ \\
\hline
\end{tabular}

Note. Student only and teacher only values refer to times where only students (many/all or few/one) or teachers, respectively, had tactile interaction with the device.

Each participant in both studies used whole-class devices more frequently than personal digital devices (or in conjunction with personal digital devices), so it is not surprising that for most, values for whole-class use are higher. The exception is Casey, who used personal devices frequently with the whole-class projector and also independent from it. In terms of students' technical interaction with whole-class devices, it was typically a very small portion of instructional time: $4 \%$ for Kathleen's students, 14\% for Krystele, $20 \%$ for Olivia, $0 \%$ for Therese, $20 \%$ for Casey, and $0 \%$ for Sharon. Of these, Kathleen was the only teacher who had students use the device independently (for centers time), but most teachers, especially Olivia, directed students' use as part of the lesson. The wholeclass device used by participants in Study 1 (i.e., the IWB) is more conducive to technical interaction, but the whole-class device most frequently used by participants in Study 2 (i.e., a data projector), requires use of a computer to interact with content. It is important to note that even in classes where frequent interaction occurred with whole-class devices, these interactions were often limited to one or two students who either pressed a button, wrote a letter, or moved a screen element (Study 1) or manipulated content displayed on the projector from the class computer (Study 2) and most students' interaction was vicarious only (Quashie, 2009). Therese, who of all participants expressed most discomfort with technology, utilized the document camera almost exclusively, not utilizing the interactive affordances of the IWB at all. Yet, of the teachers from Study 1 who had access to touchresponsive whole-class devices, significant time was used displaying content only (like a data projector) or with the device on and displaying content, but not being used as part of instruction, thereby reducing technical interactivity.

For teachers who included personal digital devices in their instruction, students had more interaction than the teachers, and often, it was many or all students who used devices at once. In most activities, teachers would have students use personal digital devices to respond to content displayed on the whole-class device (clickers for quizzes, netbooks for accessing websites displayed on the IWB or with the projector). When used, personal digital devices were utilized in ways that supported technical interactivity, rather than to display content.

\section{Pedagogic Interactivity}

A list of instructional activities in the classroom and the duration of each was prepared from the observational transcripts and coded using Dewitz, Jones, and Leahy's 
(2009) instructional categories for reading strategies instruction. Although designed for reading instruction, categories of instructional activities also apply to other curricular areas. From this list, it was determined that classroom discussion, questioning, and guided practice activities were more pedagogically interactive between teachers and students or between students than instances where there was less active involvement and exchange of ideas by either group such as when the teacher gave information, explained skills, or modelled skills; or students practiced independently at their desks. Of these activities, discussion would be the most deeply pedagogic (Smith et al., 2005) whereas simple question and answer activities where a specific response is expected would be more superficial. Question and response activities and guided practice occurred frequently in all classes; however, back and forth discussion of ideas outside of the question-and-answer format occurred infrequently.

Table 3 provides a summary of potentially pedagogically-interactive activities observed in each classroom over the course of eight (Study 1) or four (Study 2) observed lessons. For convenience, the Dewitz et al. (2009) categories were collapsed into teacheronly, student-only, and teacher + student activities with and without each type of technology use (similar to Northcote et al., 2012). Only instructional activities that had clear instructional outcomes, including but not limited to reading, have been included in the totals. Activities where students were not expected to learn or practice new content have been excluded as non-instructional (Hirst 1973). The accumulation of noninstructional time for activities such as breaks or other routines reduced the content instruction time by up to $40 \%$ in some classrooms.

Table 3

Percentage Duration of Pedagogically-Interactive Activities by Device Type

\begin{tabular}{|c|c|c|c|c|c|c|}
\hline & \multicolumn{4}{|c|}{ Study $1(\mathrm{~K}-3)$} & \multicolumn{2}{|c|}{ Study $2(4-6)$} \\
\hline & Kathleen & Krystele & Olivia & Therese & Casey & Sharon \\
\hline \multicolumn{7}{|c|}{ Whole-Class Device Use (With and Without Personal Device Use) } \\
\hline Teacher Only & $4 \%$ & $11 \%$ & $8 \%$ & $20 \%$ & $0 \%$ & $0 \%$ \\
\hline $\begin{array}{l}\text { Teacher }+ \\
\text { Student }\end{array}$ & $27 \%$ & $9 \%$ & $31 \%$ & $29 \%$ & $18 \%$ & $15 \%$ \\
\hline Student Only & $0 \%$ & $20 \%$ & $7 \%$ & $2 \%$ & $8 \%$ & $13 \%$ \\
\hline \multicolumn{7}{|c|}{ Personal Device Use (With and Without Whole-Class Device Use) } \\
\hline Teacher Only & $\mathrm{n} / \mathrm{a}$ & $\mathrm{n} / \mathrm{a}$ & $0 \%$ & $1 \%$ & $2 \%$ & $0 \%$ \\
\hline $\begin{array}{l}\text { Teacher }+ \\
\text { Student }\end{array}$ & $\mathrm{n} / \mathrm{a}$ & $\mathrm{n} / \mathrm{a}$ & $5 \%$ & $0 \%$ & $40 \%$ & $11 \%$ \\
\hline Student Only & $\mathrm{n} / \mathrm{a}$ & $\mathrm{n} / \mathrm{a}$ & $0 \%$ & $9 \%$ & $9 \%$ & $3 \%$ \\
\hline No Device Use & & & & & & \\
\hline Teacher Only & $10 \%$ & $5 \%$ & $4 \%$ & $1 \%$ & $0 \%$ & $5 \%$ \\
\hline $\begin{array}{l}\text { Teacher + } \\
\text { Student }\end{array}$ & $16 \%$ & $17 \%$ & $13 \%$ & $17 \%$ & $4 \%$ & $27 \%$ \\
\hline Student Only & $6 \%$ & $12 \%$ & $13 \%$ & $9 \%$ & $6 \%$ & $22 \%$ \\
\hline $\begin{array}{l}\text { Non- } \\
\text { Instructional }\end{array}$ & $37 \%$ & $26 \%$ & $24 \%$ & $11 \%$ & $32 \%$ & $10 \%$ \\
\hline
\end{tabular}


Note. Student only values include Dewitz et al.'s independent practice category. Teacher only values include modelling, teacher explanations, and content information provision. Teacher + Student activities are most pedagogically interactive and include questioning and class discussions. Non-Instructional refers to the percentage of time removed from analysis because it did not relate to lesson objectives (such as activity breaks) or teach new content (such as tests).

Activities with pedagogic interaction between teachers and students were the most predominant in each category (whole-class, personal digital device, and no technology use) for each teacher except for Krystele who made frequent use of independent activities because of centers. Northcote et al. (2012) suggest that a balance of all three types of activities is best to maintain student engagement in the lesson. In regards to pedagogically interactive activities that occurred with and without technology, instructional program limited pedagogical options for some teachers, especially Kathleen and Olivia who taught in a program that mandates whole-class, teacher-directed instruction. Kathleen and Olivia's instructional program mandated specific teaching strategies and, overall, many of their activities were the same, yet their use of technology was not. Olivia was an early adopter of the IWB in her school and Kathleen was more reluctant, although she had recently undertaken more training to improve her skills. Olivia expressed how she prioritized opportunities for students to use the IWB in her planning and how she used tools like clickers to elicit students' thinking so she could address her discussion to their instructional needs. The use of personal digital devices provided opportunities for students to interact with content while their teachers directed or asked questions or gave explanations in response to what they were doing. In many cases, the use of the personal digital devices facilitated pedagogically interactive activities, although not the types of interaction with content that Leu and colleagues $(2004,2008)$ might prefer where students locate, evaluate, synthesize, and communicate information in response to a problem or interest; rather, these were teacher-defined, concrete tasks with specific expectations or outcomes. And, even without technology use, teachers made frequent opportunities for pedagogically interactive activities, so it is not accurate to claim that technology use improved pedagogical interactivity, but rather, it facilitated some pedagogically interactive activities teachers chose to include in their lessons.

\section{Discussion}

In both studies, teachers spoke frequently about the interactive affordances of the devices they used and, in most cases, they defined interactivity in terms of technical interactivity. Interactivity was the most frequently mentioned benefit claimed for IWB use by the teacher participants in Study 1. Over the course of 32 interviews, there were 42 mentions of interactivity afforded by IWB use or examples shared of student interaction with the IWB (Kathleen 8, Krystele 6, Olivia 14, Therese 14), of these, 16 were positive, 17 were negative or expressed barriers to interactivity, and 7 were mixed. Yet, overall, teachers were positive about the interactive potential of IWB use. For example, when Krystele was asked to identify the main pedagogical benefit of the IWB, she spoke about the potential for new types of interactive activities:

[The main value is] the variety of interactive activities that you have available to 
you that you can do with the kids. I would think [that] would be the main thing because there's so much opportunity with it, so much you can do that will get the kids' attentions and that is nice, big, and all that. And then, all the activities they can do on there, the practice that they can do, you know? Instead of going up to the board and just writing something, there's just so much more they can do. They can sort, they can sound things out, they can write, they can associate, match... you name it they can do it. So, I think to me that's what is most valuable. It's all the different things I can do with it. The different opportunities and ideas that I can use. (Krystele, February 13)

Teachers in Study 1, especially, held strong convictions that educational technologies made their teaching more interactive. Yet, the IWB and document camera were used most frequently as a static projector with no technical interaction. Teachers in Study 2 never directly referenced interactivity as a benefit of technology use or discussed whether whole-class devices or personal digital devices permitted greater interactivity, but they did reference examples of technically interactive activities such as making opportunities for Casey's students to use the netbooks to practice quizzing each other with spelling words or asking students to find and access files on the classroom computer.

Teachers rarely expressed awareness of interactivity from a pedagogical standpoint. Sometimes, teachers spoke about the interactive affordances of different devices in ways that can be seen as pedagogic in nature, although none were identified as such by the teachers. In the following example, Olivia addressed both technical interactivity when students were manipulating screen elements on the IWB and pedagogical interactivity in her interaction with students to demonstrate the concept of rhyming:

Tuesday we did rhyming words. ... I thought 'Rhyming words, well rhyming words are easy and we'll get through this no big deal' and I had a SMART Board lesson set up. ... This time, they had pictures, so 'cat' and they had to find a picture that rhymed with the word cat. ... They each got to come up one at a time 'cat' and they'd put 'cow' and they'd put it [the picture] in there. And I'd say 'cowwwww' and 'cat', do those two rhyme? Because they were thinking of the initial sounds and not ending sounds. So, again it was a bit of a learning curve for me because I went, 'Ok there are some kids that can't rhyme in this classroom', but prior to that, I don't know I may have not known that because it would have been very auditory. We would have done a little bit of activity, maybe we would have read a book about rhyming, a rhyming book where I got the kids to find the rhyming words and then we would have done the workbook pages. (Olivia, January 12)

In Olivia's example, she recognized that the activity done on the IWB facilitated her understanding of a gap in her students' knowledge and helped her to address the gap in a way that her traditional practices would not.

\section{Barriers to Interactivity}

Mohon (2008) and Quashie (2009) reported barriers to interactivity posed by the capacity of touch-sensitive whole-class technologies to recognize only one point of contact (touch). Thus, it is not surprising students' technical interaction with touch-sensitive 
whole-class devices in these studies was limited, despite manufacturers' claims of improved interaction (Sadler Jones, 2012). Some teachers faced barriers based on the allowable pedagogical strategies of their instructional program; yet, even in the absence of mandated teaching methods that emphasize teacher-directed instruction, it cannot be assumed students have frequent technical interaction with whole-class technologies. Permitting all students to have meaningful, individual interaction with touch-sensitive whole-class devices is time consuming and slows lesson pacing. Additionally, some schools (such as in Study 2) are moving away from touch-sensitive devices towards data projectors which display the same content but do not react to touch. The introduction of personal devices, especially to support the content displayed on whole-class devices, enables more students to have technical interaction with devices but is dependent upon availability of devices (Norris et al., 2003).

More than access and program requirements, teachers' personal teaching styles and choices and, particularly, their comfort level with technology, appeared to influence whether technologies were used in technically and pedagogically interactive ways. Mishra and Koehler's (2006) TPCK model describes the interaction between pedagogy and content knowledge in the presence of technology use. In this model, technology can support teachers' pedagogy and content knowledge, and a balance between the content, appropriate teaching methods (pedagogy), and technology use is preferred. It makes sense that teachers who are more comfortable with technology have more support for using it in more pedagogically engaging ways, regardless of the demands of their program, and make opportunities for different types of devices that increase opportunities for students' technical interaction with devices as well. In these studies, teachers who were less confident or adept made fewer opportunities for technology use by students, had more teacher-directed use of devices, and used fewer types of technology in less diverse ways. Some used devices as whiteboard substitutes (Beauchamp 2004) or overhead projector substitutes, replicating traditional, teacher-directed pedagogies on the new medium.

A third barrier was in the structure of activities themselves, either with or without technology use. Northcote et al. (2012) explained that students' engagement is maximized when teachers mix teacher-only, student-only, and joint activities within lessons. Each participant had a mixture of all three types of activities; however, many pedagogically interactive activities observed involved teacher provision of information with questioning. Teachers' questions tended to require limited or closed responses from the students (i.e., factual recall questions) and thus would be at a shallower level of pedagogic interactivity (Hennessy et al., 2007; Smith et al., 2005) than activities where students and teachers discuss topics in a back and forth manner, constructing their topic understandings by discussion, research, and problem solving. Activities where students engaged in back and forth discussion and knowledge construction along lines of student and teacher inquiry were infrequent in both studies. Similarly, the capacity of Internet-capable devices to do research on the Internet or to communicate with others outside the classroom was not observed.

\section{Conclusions}

Teacher participants were positive in their reports about the benefits of technology use for interactivity, despite their acknowledgement of barriers to interaction. Teachers' comments about interactivity in Study 1 were often vague and did not distinguish between 
the potential for technical and for pedagogical interactivity (i.e. stating 'It's more interactive'); however, their comments were typically related to the potential for increased technical interactivity. Yet, the analysis of activities in which teachers and students interacted with the whole class technology has shown that in most of the classrooms, students spent much of their time passively watching displayed data on the whole-class device or watching their teachers interact with the device. Even in classrooms where students had frequent interaction with the devices, whether whole-class or personal, rarely did all students have physical contact with technology during any lesson. Thus, most students' interaction in the current study was vicarious as defined by Quashie (2009).

Examples of pedagogical interactivity are more complex to identify and define than technical interactivity. Pedagogical interactivity refers to the interaction between the teacher and students during instruction and is often reported as teacher-pupil interaction through questioning (Hennessy et al., 2007; Smith et al., 2005). Smith and Hennessy questioned the quality of the pedagogical interaction that occurs with whole-class device use such as with IWBs, particularly when teachers' questioning is intended to elicit one 'correct' response. The pattern of teachers questioning students using "known information questions" is well established in the literature (Mehan, 1979) and serves to reproduce cultural knowledge and understandings (Heap, 1985). Known information questions are a form of assessment, rather than teaching; teachers will use additional questions or comments to "search" for the answer they wish to hear (Mehan), rather than co-construct understanding, similar to Hennessy and colleagues' (2007) phenomenon of "funnelling".

Discussion, where there was an interplay of ideas between teachers and students, rather than teacher questions and student responses, was nearly non-existent in the classrooms under study. Guided practice was prevalent, but even so, teachers were guiding students to one 'correct' method of performing a task. Thus, even though interaction between teachers and students was frequent, the nature of the interactivity and interchange of ideas was constrained by the teachers' transmission of knowledge and skills to students and this model is no different than the interaction that reportedly occurred between teachers and students in 'traditional' classrooms without technology use such as Mehan (1979) reported. Thus the technology was replicating and reinforcing existing traditional information transmission pedagogies (Bauer \& Kenton, 2005) such as in Beauchamp's (2004) concept of the blackboard/whiteboard substitute.

The results of this study challenge existing claims, especially by manufacturers (Lovell \& Phillips, 2012; Saddler Jones, 2012) and technology advocates, that technology use transforms teachers' pedagogy by improving interactivity. Unlike some studies of pedagogical change or of interactivity, I made repeat observations of each classroom over time and gathered data on the duration and types of technology usage and of interaction by both teachers and students so I could be confident that teachers' true practices were reflected in the observations. Teachers in these studies stated that they used technology to facilitate interactivity in their lessons, but prolonged observation, coupled with the debriefing interviews, helped clarify whether and how their perceptions about this interactivity manifested in their practice, providing a more in-depth analysis than perceptions with or without more limited observation would allow. Thus, contrary to the findings of researchers such as Haldane (2007) and Gray et al. (2005) who relied on anecdotal remarks and limited observation, I was able to show that the teachers in my studies demonstrated: 
- varying levels of technical and pedagogical interactivity in their teaching, despite most participants' perception that technology use makes their teaching more interactive;

- varying active use of the various educational technologies and no consistency in the length of use between lessons; and

- little change in the proportion of pedagogically interactive to non-interactive teaching methods each participant used in her class overall, despite platform type.

This article adds to the growing body of research that takes a critical stance on pedagogical changes that occur with technology adoption (i.e., Mohon, 2008; Quashie, 2009; Smith et al., 2005). These studies show that although adoption and use may have positive benefits for teaching and learning in the early grades and particularly for interactivity, these benefits are not automatic, but are based on teachers' pedagogical decision-making processes for each teaching context. This research is among the first to report on and compare the duration and type of interaction with the IWB by both teachers and students over time. Furthermore, I examined pedagogical change from the perspective of both teachers' and students' actions in the classroom in an attempt to address Olson's (2010) critique studies of pedagogy ignore the purposeful actions of the teacher that are intended to bring about learning (Hirst, 1973). Olson argued that most recent studies of pedagogy do not analyse teachers' purposeful actions intended to promote learning but, rather, focus on assessing measurable outcomes such as changes in grades or scores on tests as evidence that learning has occurred. These studies, Olson argues, advance the idea of generalized "best practices" that are meant to be successful for promoting learning across contexts. In the current studies, I focused on teachers' purposeful actions and activities that were intended to be instructional. The teachers' use of technology to support learning varied across lessons and contexts - no teacher used the technology in exactly the same way in two lessons. No "best practice" for technology use emerged; however, it is important to note that each teacher used the technology in a way that suited the specific learning task and context.

\section{Limitations}

Like many case studies, these studies have a small sample size and thus, generalizability of results is limited. However, my findings support those of other researchers such as Mohon (2008) and Quashie (2009) that technology use does not always result in increased interactivity. I highlighted flaws in existing research, namely the failure define interactivity and to compare lessons when technology is in use with when it was not in use in order to examine teachers' perceptions about their pedagogy and interactivity. I observed teachers at a time in their technology use when all were at least moderately comfortable with technology and used devices on a daily basis. A comparison of technology users and non-users, or between proficient users and new users, could provide more support for claims of improvements to pedagogy or interactivity.

\section{References}

Andresen, B. (2017). The acquisition of literacy skills in 1:1 classrooms - the Danish case. Education and Information Technology, 22(2), 533-550. 
doi:10.1007/s10639-016-9488-7

Bauer, J., \& Kenton, J. (2005). Toward technology integration in the schools: Why it isn't happening. Journal of Technology and Teacher Education, 13(4), 519-546.

Retrieved from https://www.learntechlib.org/primary/p/4728/

Beauchamp, G. (2004). Teacher use of the interactive whiteboard in primary schools:

Towards an effective transition framework. Technology, Pedagogy and

Education, 13(1), 327-348. doi:10.1080/14759390400200186

Butzin, S. (2001). Using instructional technology in transformed learning environments: An evaluation of Project CHILD. Journal of Research on Computing in Education, 33(4), 367-373. doi:10.1080/08886504.2001.10782321

Camtasia Studio 7 [Computer Software]. (2010). Okemos, MI: TechSmith.

Cheng, K. (2017). Exploring parents' conceptions of augmented reality learning and approaches to learning by augmented reality with their children. Journal of Educational Computing Research, 55(6), 820-843. doi: $10.1177 / 0735633116686082$

Curcic, S., \& Johnstone, R. (2016). The effects of an intervention in writing with digital interactive books. Computers in the Schools, 33(2), 71-88. doi: $10.1080 / 07380569.2016 .1181478$

de Koster, S., Volman, M., \& Kuiper, E. (2013). Interactivity with the interactive whiteboard in traditional and innovative primary schools: An exploratory story. Australasian Journal of Educational Technology, 29(4), 480-495. doi:10.14742/ajet.291

Dewitz, P., Jones, J., \& Leahy, S. (2009). Comprehension strategy instruction in core reading programs. Reading Research Quarterly, 44(2), 102-126. doi:10.1598/RRQ.41.2.1

Franklin, C. (2007). Factors that influence elementary teachers' use of computers. Journal of Technology and Teacher Education, 15(2), 267-293.

Froese-Germain, B., Riel, R., \& McGahey, B. (2013, January). Teachers' views on the relationship between technology and aspirational teaching: Findings from a CTF national survey. Retrieved from https://www.ctf-fce.ca/Research-Library/technologyandaspirationalteaching.pdf

Gray, C., Hagger-Vaughan, L., Pilkington, R., \& Tomkins, S. (2005). The pros and cons of interactive whiteboards in relation to the Key Stage 3 Strategy and Framework. The Language Learning Journal, 32(1), 38-44. doi:10.1080/09571730585200171

Haldane, M. (2007). Interactivity and the digital whiteboard: Weaving the fabric of learning. Learning, Media and Technology, 32(3), 257-270. doi:10.1080/17439880701511107

Heap, J. (1985). Discourse in the production of classroom knowledge: Reading lessons. Curriculum Inquiry, 15(3), 245-279. doi:10.1080/03626784.1985.11075966

Hennessy, S., Deaney, R., Ruthven, K. \& Winterbottom, M. (2007). Pedagogical strategies for using the interactive whiteboard to foster learner participation in school science. Learning, Media and Technology, 32(3), 283-301. doi:10.1080/17439880701511131

Hirst, P. (1973). What is teaching? In R. Peters (Ed.), The philosophy of teaching (pp. 163-177). Oxford, UK: Oxford University Press.

Hooper, S., \& Rieber, L. (1999). Teaching, instruction, and technology. In A. Ornstein, \& 
L. Behar-Horenstein (Eds.), Contemporary issues in curriculum (pp. 252-264).

Boston, MA: Allyn and Bacon.

Leu, D., Coiro, J., Castek, J., Hartmann, D., Henry, L., \& Reinking, D. (2008). Research on instruction and assessment in the new literacies of online reading comprehension. In C. Collins Block, \& S. Paris (Eds.), Comprehension instruction: Research-based best practices (pp. 321-346). New York: Guilford.

Leu, D., Kinzer, C., Coiro, J., \& Cammack, D. (2004). Toward a theory of new literacies emerging from the internet and other information and communication technologies. In R. Ruddell \& N. Unrau (Eds.), Theoretical models and processes of reading. 5th ed. (pp. 1570-1613). Newark, DE: International Reading Association.

Lopez, O. S. (2010). The digital learning classroom: Improving English language learners' academic success in mathematics and reading using interactive whiteboard technology. Computers \& Education, 54(4), 901-915. doi:10.1016/j.compedu.2009.09.019

Lovell, M. A. (2014). Interactive whiteboard use: Changes in teacher pedagogy in reading instruction in the primary grades (Unpublished doctoral dissertation). University of Alberta, Edmonton, AB. doi:10.7939/R37M0480G

Lovell, M. A., \& Phillips, L. M. (2012). Exposing technomyths: Getting technical about technology and teaching. Education Canada, 52(4). Retrieved from http://www.cea-ace.ca/education-canada/article/web-exclusive-exposingtechnomyths-getting-technical-about-technology-and-t

Maher, D. (2011). Using the multimodal affordances of the interactive whiteboard to support students' understanding of texts. Learning, Media and Technology, 36(3), 235-250. doi:10.1080/17439884.2010.536553

Mehan, H. (1979). 'What time is it, Denise?": Asking known information questions in classroom discourse. Theory into Practice, 18(4), 285-294.

Mishra, P., \& Koehler, M.J. (2006). Technological pedagogical content knowledge: A framework for teacher knowledge. Teachers College Record, 108(6), 1017-1054.

Mohon, E. H. (2008). SMART moves? A case study of one teacher's pedagogical change through use of the interactive whiteboard, Learning, Media and Technology, 33(4), 301-312. doi:10.1080/17439880802497032

Norris, C., Sullivan, T., Poirot, J., \& Soloway, E. (2003). No access, no use, no impact: Snapshot surveys of educational technology in K-12. Journal of Research on Technology in Education, 36(1), 15-27. doi:10.1080/15391523.2003.10782400

Northcote, M., McQuillan, K., \& Beamish, P. (2012). What matters most when students and teachers use interactive whiteboards in mathematics classrooms? Australian Primary Mathematics Classroom, 17(4), 3-7.

Olson, D. R. (2010). Whatever happened to pedagogical theory? In D. Aram \& O. Korat (Eds.). Literacy development and enhancement across orthographies and cultures. (pp. 223-234). doi:10.1007/978-1-4419-0834-6_16

Passey, D., Rogers, C., Machell, J., McHugh, G., \& Allaway, D. (2003). The motivational effect of ICT on pupils: Emerging findings. London: DfES.

Quashie, V. (2009). How interactive is the interactive whiteboard? Mathematics Teaching Incorporating Micromath, 214, 33-38.

Sadler Jones, H. (2012). A solid foundation of success: Research supports the 
effectiveness of interactive whiteboards. Education Canada. Retrieved from http://www.cea-ace.ca/education-canada/article/web-exclusive-exposingtechnomyths-getting-technical-about-technology-and-t

Serow, P., \& Callingham, R. (2011). Levels of use of the interactive whiteboard technology in the primary mathematics classroom. Technology, Pedagogy and Education, 20(2), 161-17. doi:10.1080/1475939X.2011.588418

SMART Technologies. (2015). SMART for Education. Retrieved from http://education.smarttech.com/en/about/our-solutions

Smith, H. J., Higgins, S., Wall, K., \& Miller, J. (2005). Interactive whiteboards: Boon or bandwagon? A critical review of the literature. Journal of Computer Assisted

Learning, 21(2), 91-101. doi:10.1111/j.1365-2729.2005.00117.x

Author Biography

Meridith Lovell-Johnston is an assistant professor in the Faculty of Education at Lakehead University's Orillia Campus. Meridith graduated with her $\mathrm{PhD}$ in language and literacy from the University of Alberta in 2014. Her research areas include reading pedagogy and assessment and the integration of technology into teaching. Her most recent projects investigate the implementation of literacy and inquiry practices within the FullDay Kindergarten model in Ontario and the development of self-regulation and literacy capacity amongst Indigenous children in Northern Ontario. 
Appendix 1: Code List and Exemplars for Interview Data

\begin{tabular}{ll}
\hline Code & Criteria or Exemplar \\
\hline Interactivity & $\begin{array}{l}\text { Criterion: One of these specific key words was mentioned or } \\
\text { the teacher discussed someone touching the technology }\end{array}$ \\
Interactivity - Positive & $\begin{array}{l}\text { So, it was much tougher to get the lesson across before I had } \\
\text { the SMART Board. Now I can go on ... I can Google things, } \\
\text { and I can show them on the SMART Board and then I can } \\
\text { bring a SMART Board lesson in and I can get the kids to be } \\
\text { interactive with it and it just makes a huge difference. I think } \\
\text { they understand so much better than just me, you know, the } \\
\text { teacher, being the one teaching. Now the SMART Board is } \\
\text { doing some of the teaching, right? They are figuring things } \\
\text { out by themselves by manipulating things on the SMART } \\
\text { Board. (Olivia) }\end{array}$
\end{tabular}

Some of the science things that I add in, like temperature is part of it too, being able to have that visual where we can actually move the temperature and talk about "It's supposed to go down to here" and stuff, I think - we used to have those big ones with the ribbon that you had to pull through and, yeah, so not so much what they're learning but how they're learning is much more visual, it's much more interactive, not that they're interacting with it, but I'm able to manipulate it and they can see what's happening. So it changed how we learn it, and I think it makes it easier for them to understand, especially when they don't have the language they can see it happening. (Kathleen)

Interactivity - Negative And there are times, and we haven't done it yet, I find that kids do not write well on that Interactive Whiteboard. Their hands go down and they can't print (gestures hand flat against the board). So, I learned that right away when I first got my SMART Board, I tried to have the kids writing the answers in, which is great, but you just can't do it. It takes them forever. They'll write one letter, then they'll try to write the second one, they'll make a mistake so they'll erase it and they'll erase the first letter too (laughs). So, it's very difficult to get the kids to write on there, so if there was some way that I could get them to do that, it would be great. But, I just find with grade one and two, they're not there yet, they're not ready. (Olivia)

So, I try and do some things but, in all honesty, I would have 
to say that those SMART Book lessons you know where it's off of the document camera and it's on the whiteboard interactively is for math mostly, I would say. I think Language Arts, ... you almost need that book in your hands. Like that physical book in your hands - be it a picture book, or moving on through the grades, a chapter book. (Therese)

Interactivity - Neutral / Mixed
I think that it increases interactivity in elementary. I think that when you look at the SMART Board in junior high or high school, from the teachers that I've talked about it with I know a lot of teachers - and they're completely different. But, in elementary, definitely because they can go to the board, it can be interactive, they can do activities on there just like they were doing yesterday and that's great for them. That helps them learn because they need to do to learn, they can't just hear. So, I think that helps a lot in elementary. But as the kids get older of course, they're more susceptible to what others are thinking and so therefore they don't want to go to the board anymore. That's bad to be called to the board to do an example because everyone's watching and there's all that peer pressure, right? So, I don't think that in junior high and high school it's as useful in that way than it is in elementary. (Krystele)

Well, I find that generally you turn on the SMART Board and it's like turning on the TV. They're focussed on it. But, of course it depends what it is. If you're doing something that's interactive, something that demands thought? They can get off track more easily because they're 5 year olds and they have a short attention span. (Krystele) 
Appendix 2: Observation Codes and Criteria or Exemplars (Technical and Pedagogic)

Tactile Interaction Codes

\begin{tabular}{|c|c|}
\hline Code & Criteria \\
\hline $\begin{array}{l}\text { Student Contact / } \\
\text { Tactile Interact (S) }\end{array}$ & $\begin{array}{l}\text { Student made direct tactile contact with the device. Further } \\
\text { broken down into single/some vs many/all students to } \\
\text { distinguish between when a few or one student uses the } \\
\text { device or when all or most students use the devices. }\end{array}$ \\
\hline $\begin{array}{l}\text { Teacher }+ \text { Student } \\
\text { Contact /Tactile Interact } \\
(\mathrm{T}+\mathrm{S})\end{array}$ & $\begin{array}{l}\text { Teacher directed the students' use or teacher and student } \\
\text { took turns interacting with the device. }\end{array}$ \\
\hline $\begin{array}{l}\text { Teacher Contact / } \\
\text { Tactile Interact ( } \mathrm{T})\end{array}$ & $\begin{array}{l}\text { Teacher made direct tactile contact with the device (either } \\
\text { the IWB or the projector via teacher's computer). }\end{array}$ \\
\hline Student - Peripheral & $\begin{array}{l}\text { Students used a peripheral device such as a clicker to } \\
\text { interact with a whole-class device. }\end{array}$ \\
\hline Teacher - Peripheral & $\begin{array}{l}\text { Teacher used a peripheral device such as a document camera } \\
\text { that displays on the whole-class device. }\end{array}$ \\
\hline Display & $\begin{array}{l}\text { Content is displayed on the device. No direct tactile contact } \\
\text { or use of peripheral devices to manipulate content. }\end{array}$ \\
\hline Mentioned & $\begin{array}{l}\text { The teacher mentions the device. For example, "Sit by the } \\
\text { Smart board" or "Take out your netbooks". }\end{array}$ \\
\hline On/Off/Not Used & $\begin{array}{l}\text { No device is in use or all technology is turned off. Also, the } \\
\text { device could be turned on but neither mentioned nor referred } \\
\text { to in the lesson. }\end{array}$ \\
\hline
\end{tabular}


Instructional Activities / Pedagogic Interaction Codes and Criteria

\begin{tabular}{|c|c|c|}
\hline Code & Criteria (Adapted from Dewitz et al.) & Collapsed Code \\
\hline Mention & $\begin{array}{l}\text { Teacher mentions a skill or tells students to } \\
\text { perform the skill but does not provide } \\
\text { further directions, models, explanations. }\end{array}$ & Teacher Only \\
\hline Skill + Explain & $\begin{array}{l}\text { Skill or strategy is mentioned and described } \\
\text { but no modeling of the process takes place. } \\
\text { Descriptions explain the skill, but no } \\
\text { procedural information is provided. }\end{array}$ & Teacher Only \\
\hline Model & $\begin{array}{l}\text { The teacher demonstrates how to do the } \\
\text { skill or the strategy (i.e., a think-aloud). }\end{array}$ & Teacher Only \\
\hline Information & $\begin{array}{l}\text { The teacher gives information about the } \\
\text { content of the selection. This code is also } \\
\text { used for when the teacher is reading to the } \\
\text { students. }\end{array}$ & Teacher Only \\
\hline Question & The teacher asks a question. & Teacher + Student \\
\hline Question + Model & $\begin{array}{l}\text { The teacher asks a question and then models } \\
\text { the strategy while answering it. }\end{array}$ & Teacher + Student \\
\hline $\begin{array}{l}\text { Information + } \\
\text { Question }\end{array}$ & $\begin{array}{l}\text { The teacher provides information (or reads } \\
\text { information to students) and questions them } \\
\text { during or after. }\end{array}$ & Teacher + Student \\
\hline Guided Practice & $\begin{array}{l}\text { Students practice the skill, but the teacher } \\
\text { provides some support through } \\
\text { explanations, hints, or directions. }\end{array}$ & Teacher + Student \\
\hline Direct Explanation & $\begin{array}{l}\text { The teacher explains a skill or strategy and } \\
\text { provides declarative, procedural, and } \\
\text { conditional information. }\end{array}$ & Teacher Only \\
\hline $\begin{array}{l}\text { Independent } \\
\text { Practice }\end{array}$ & $\begin{array}{l}\text { Students practice the skill, typically on a } \\
\text { worksheet or graphic organizer. }\end{array}$ & Student Only \\
\hline Discussion & $\begin{array}{l}\text { The teachers asks questions, points out or } \\
\text { discusses ideas, and has the students discuss } \\
\text { ideas. The flow of ideas and questions goes } \\
\text { both ways - i.e., not just the teacher asking } \\
\text { questions and the students responding - } \\
\text { students may pose questions or raise areas }\end{array}$ & Teacher + Student \\
\hline
\end{tabular}


of their own interest.

Non-Instructional Teacher is not addressing new content (i.e., None transitions, tests, review activities, movement breaks, morning routines). 


\section{Appendix 3: Lesson Summary Example Using Codes from Appendix 2}

\section{Krystele's Lesson: Kindergarten (Excerpt)}

\begin{tabular}{|c|c|c|c|c|c|c|}
\hline $\begin{array}{l}\text { Activity / } \\
\text { Duration }\end{array}$ & $\begin{array}{l}\text { Time / } \\
\text { Activity }\end{array}$ & Objective & $\begin{array}{l}\text { Instructional } \\
\text { Method. } \\
\text { (Dewitz) }\end{array}$ & $\begin{array}{l}\text { IWB } \\
\text { Used? / } \\
\text { How? }\end{array}$ & Who & $\begin{array}{l}\text { Description of } \\
\text { Activities }\end{array}$ \\
\hline \multirow[t]{6}{*}{$\begin{array}{l}\text { Story } \\
\text { Reading } \\
\text { with } \\
\text { activities } \\
(10: 32)\end{array}$} & $\begin{array}{l}20: 16- \\
20: 57\end{array}$ & $-n / a$ & $\begin{array}{l}\text { Non- } \\
\text { Instructional }\end{array}$ & $\begin{array}{l}\text { Yes - } \\
\text { Mentions }\end{array}$ & $\begin{array}{l}\text { Teacher } \\
+ \text { Class }\end{array}$ & $\begin{array}{l}\text { Transition time } \\
\text { during which the } \\
\text { teacher directed } \\
\text { students to sit on } \\
\text { the ground in } \\
\text { front of the IWB }\end{array}$ \\
\hline & $\begin{array}{l}20: 57- \\
21: 59\end{array}$ & $\begin{array}{l}\text { - Reading, } \\
\text { comprehension, } \\
\text { vocabulary }\end{array}$ & Information & $\begin{array}{l}\text { Yes - } \\
\text { Display }\end{array}$ & $\begin{array}{l}\text { Teacher } \\
+ \text { Class }\end{array}$ & $\begin{array}{l}\text { IWB read the } \\
\text { "story" On Top } \\
\text { of Spaghetti to } \\
\text { the students. }\end{array}$ \\
\hline & $\begin{array}{l}21: 59- \\
22: 36\end{array}$ & $\begin{array}{l}\text { - Reading, } \\
\text { comprehension, } \\
\text { vocabulary }\end{array}$ & Information & $\begin{array}{l}\text { Yes - } \\
\text { Display }\end{array}$ & $\begin{array}{l}\text { Teacher } \\
+ \text { Class }\end{array}$ & $\begin{array}{l}\text { Teacher said that } \\
\text { they would read } \\
\text { the story } \\
\text { together. But, } \\
\text { teacher and } \\
\text { students echoed } \\
\text { some of the } \\
\text { words after the } \\
\text { IWB. }\end{array}$ \\
\hline & $\begin{array}{l}22: 36- \\
23: 07\end{array}$ & $\begin{array}{l}\text { - Reading, } \\
\text { comprehension, } \\
\text { vocabulary }\end{array}$ & Discussion & $\begin{array}{l}\text { Yes - } \\
\text { Display }\end{array}$ & $\begin{array}{l}\text { Teacher } \\
+1 \\
\text { student }\end{array}$ & $\begin{array}{l}\text { One student } \\
\text { made a comment } \\
\text { about the story } \\
\text { being sad. Then } \\
\text { the teacher and } \\
\text { student } \\
\text { discussed why } \\
\text { the story might } \\
\text { be sad. }\end{array}$ \\
\hline & $\begin{array}{l}23: 07- \\
24: 25\end{array}$ & $\begin{array}{l}\text { - Comprehension, } \\
\text { story } \\
\text { sequencing }\end{array}$ & $\begin{array}{l}\text { Guided } \\
\text { Practice }\end{array}$ & $\begin{array}{l}\text { Yes - } \\
\text { Tactile } \\
\text { Interact } \\
(\mathrm{T})\end{array}$ & $\begin{array}{l}\text { Teacher } \\
+ \text { class }\end{array}$ & $\begin{array}{l}\text { Story board } \\
\text { activity in which } \\
\text { the class } \\
\text { organized } \\
\text { pictures in story } \\
\text { sequence. }\end{array}$ \\
\hline & $\begin{array}{l}24: 25- \\
27: 26\end{array}$ & $\begin{array}{l}\text { - Letter sounds, } \\
\text { sounding out } \\
\text { words }\end{array}$ & Question & $\begin{array}{l}\text { Yes - } \\
\text { Tactile } \\
\text { Interact } \\
(\mathrm{T})\end{array}$ & $\begin{array}{l}\text { Teacher } \\
+ \text { class }\end{array}$ & $\begin{array}{l}\text { Teacher asked } \\
\text { students to } \\
\text { determine the } \\
\text { order of the } \\
\text { letters for } \\
\text { scrambled words } \\
\text { from the story. }\end{array}$ \\
\hline
\end{tabular}




\begin{tabular}{|c|c|c|c|c|c|c|}
\hline \multirow[t]{2}{*}{$\begin{array}{l}\text { Activity / } \\
\text { Duration }\end{array}$} & $\begin{array}{l}\text { Time / } \\
\text { Activity }\end{array}$ & Objective & $\begin{array}{l}\text { Instructional } \\
\text { Method. } \\
\text { (Dewitz) }\end{array}$ & $\begin{array}{l}\text { IWB } \\
\text { Used? / } \\
\text { How? } \\
\end{array}$ & Who & $\begin{array}{l}\text { Description of } \\
\text { Activities }\end{array}$ \\
\hline & $\begin{array}{l}27: 26- \\
30: 48\end{array}$ & $\begin{array}{l}\text { - Problem solving } \\
\text { ability? }\end{array}$ & $\begin{array}{l}\text { Guided } \\
\text { Practice }\end{array}$ & $\begin{array}{l}\text { Yes - } \\
\text { Tactile } \\
\text { Interact } \\
(\mathrm{T} / \mathrm{S})\end{array}$ & $\begin{array}{l}\text { Teacher } \\
+ \text { class }\end{array}$ & $\begin{array}{l}\text { Teacher asked } \\
\text { students to help } \\
\text { her solve a } \\
\text { jigsaw puzzle } \\
\text { with } 7 \text { pieces } \\
\text { (and } 9 \text { students). } \\
\text { The intention } \\
\text { was to have } \\
\text { students move } \\
\text { the pieces, but } \\
\text { they weren't } \\
\text { working } \\
\text { properly so she } \\
\text { moved them } \\
\text { herself. }\end{array}$ \\
\hline \multirow[t]{4}{*}{$\begin{array}{l}\text { Letter of } \\
\text { the Week / } \\
\text { Printing } \\
(42: 46)\end{array}$} & $\begin{array}{l}30: 48- \\
31: 31\end{array}$ & $-n / a$ & Information & $\begin{array}{l}\text { Yes - } \\
\text { Display }\end{array}$ & $\begin{array}{l}\text { Teacher } \\
+ \text { Class }\end{array}$ & $\begin{array}{l}\text { Teacher explains } \\
\text { lesson for the } \\
\text { day and the } \\
\text { activities } \\
\text { students will be } \\
\text { doing with the } \\
\text { letter I. }\end{array}$ \\
\hline & $\begin{array}{l}31: 31- \\
32: 10\end{array}$ & $\begin{array}{l}\text { - letters of the } \\
\text { alphabet, letter } \\
\text { recognition }\end{array}$ & Question & $\begin{array}{l}\text { IWB Not } \\
\text { Used }\end{array}$ & $\begin{array}{l}\text { Teacher } \\
+ \text { class }\end{array}$ & $\begin{array}{l}\text { Teacher asks } \\
\text { students to } \\
\text { suggest words } \\
\text { that begin with } \\
\text { the letter I. }\end{array}$ \\
\hline & $\begin{array}{l}32: 10- \\
33: 11\end{array}$ & $\begin{array}{l}\text { - letters of the } \\
\text { alphabet, letter } \\
\text { recognition }\end{array}$ & $\begin{array}{l}\text { Information } \\
+ \text { Question }\end{array}$ & $\begin{array}{l}\text { Yes - } \\
\text { Display }\end{array}$ & $\begin{array}{l}\text { Teacher } \\
+ \text { Class }\end{array}$ & $\begin{array}{l}\text { Teacher read a } \\
\text { 'story' with } \\
\text { students which } \\
\text { consisted of } \\
\text { about three } \\
\text { pages with } \\
\text { pictures and a } \\
\text { few words. }\end{array}$ \\
\hline & $\begin{array}{l}33: 11- \\
34: 47\end{array}$ & $\begin{array}{l}\text { - letters of the } \\
\text { alphabet, letter } \\
\text { recognition }\end{array}$ & $\begin{array}{l}\text { Question + } \\
\text { Model }\end{array}$ & $\begin{array}{l}\text { Yes - } \\
\text { Tactile } \\
\text { Interact } \\
(\mathrm{T})\end{array}$ & Teacher & $\begin{array}{l}\text { Teacher } \\
\text { modelled } \\
\text { moving the } \\
\text { upper and lower } \\
\text { case Is into their } \\
\text { jars (sorting). } \\
\text { She asked } \\
\text { students to tell } \\
\text { her in which jar } \\
\text { she should put } \\
\text { each I. }\end{array}$ \\
\hline
\end{tabular}




\begin{tabular}{|c|c|c|c|c|c|c|}
\hline $\begin{array}{l}\text { Activity / } \\
\text { Duration }\end{array}$ & $\begin{array}{l}\text { Time / } \\
\text { Activity }\end{array}$ & Objective & $\begin{array}{l}\text { Instructional } \\
\text { Method. } \\
\text { (Dewitz) }\end{array}$ & $\begin{array}{l}\text { IWB } \\
\text { Used? / } \\
\text { How? }\end{array}$ & Who & $\begin{array}{l}\text { Description of } \\
\text { Activities }\end{array}$ \\
\hline & $\begin{array}{l}34: 47- \\
36: 02\end{array}$ & $\begin{array}{l}\text { - letters of the } \\
\text { alphabet, letter } \\
\text { recognition, } \\
\text { letter formation }\end{array}$ & Model & $\begin{array}{l}\text { Yes - } \\
\text { Tactile } \\
\text { Interact } \\
\text { (T) } \\
\text { (writing) }\end{array}$ & Teacher & $\begin{array}{l}\text { Teacher } \\
\text { demonstrates } \\
\text { how to form I } \\
\text { and i on the } \\
\text { IWB. But then } \\
\text { the IWB stopped } \\
\text { responding, so } \\
\text { she moved the } \\
\text { students to the } \\
\text { carpet. }\end{array}$ \\
\hline & $\begin{array}{l}36: 02- \\
40: 11\end{array}$ & $\begin{array}{l}\text { - letters of the } \\
\text { alphabet, letter } \\
\text { recognition, } \\
\text { letter formation }\end{array}$ & $\begin{array}{l}\text { Question + } \\
\text { Model }\end{array}$ & $\begin{array}{l}\text { IWB Not } \\
\text { Used }\end{array}$ & $\begin{array}{l}\text { Teacher } \\
\text { + class }\end{array}$ & $\begin{array}{l}\text { Teacher } \\
\text { demonstrates } \\
\text { how to form I } \\
\text { and i at the } \\
\text { carpet. Teacher } \\
\text { demonstrates } \\
\text { common } \\
\text { mistakes in letter } \\
\text { formation and } \\
\text { asks students to } \\
\text { analyse why they } \\
\text { are wrong. }\end{array}$ \\
\hline & $\begin{array}{l}40: 11- \\
41: 07\end{array}$ & $\begin{array}{l}\text { - letters of the } \\
\text { alphabet, letter } \\
\text { recognition, } \\
\text { letter formation }\end{array}$ & Information & $\begin{array}{l}\text { Yes - } \\
\text { Mentioned }\end{array}$ & Teacher & $\begin{array}{l}\text { Teacher explains } \\
\text { the work that } \\
\text { students will } \\
\text { complete at their } \\
\text { desks and on the } \\
\text { IWB. }\end{array}$ \\
\hline & $\begin{array}{l}41: 07- \\
43: 46\end{array}$ & $\begin{array}{l}\text { - Letter } \\
\text { sounds }\end{array}$ & $\begin{array}{l}\text { Guided } \\
\text { Practice }\end{array}$ & $\begin{array}{l}\text { IWB Not } \\
\text { Used }\end{array}$ & $\begin{array}{l}\text { Teacher } \\
+ \text { class }\end{array}$ & $\begin{array}{l}\text { Teacher } \\
\text { introduced a new } \\
\text { program she } \\
\text { would be using } \\
\text { with them that } \\
\text { included letter } \\
\text { sounds coupled } \\
\text { with actions. } \\
\text { Teacher } \\
\text { introduced all } \\
\text { the sound-action } \\
\text { combinations } \\
\text { from A-I. }\end{array}$ \\
\hline & $\begin{array}{l}43: 46- \\
52: 27\end{array}$ & $\begin{array}{l}\text { - letters of the } \\
\text { alphabet, letter } \\
\text { recognition, } \\
\text { letter formation }\end{array}$ & $\begin{array}{l}\text { Independent } \\
\text { Practice }\end{array}$ & $\begin{array}{l}\text { IWB Not } \\
\text { Used }\end{array}$ & Students & $\begin{array}{l}\text { Students worked } \\
\text { at their desks on } \\
\text { the worksheets. } \\
\text { When they were } \\
\text { finished, they } \\
\text { were able to } \\
\text { work on the } \\
\text { IWB as well. }\end{array}$ \\
\hline
\end{tabular}




\begin{tabular}{|l|l|l|l|l|l|l|}
\hline $\begin{array}{l}\text { Activity / } \\
\text { Duration }\end{array}$ & $\begin{array}{l}\text { Time / } \\
\text { Activity }\end{array}$ & Objective & $\begin{array}{l}\text { Instructional } \\
\text { Method. } \\
\text { (Dewitz) }\end{array}$ & $\begin{array}{l}\text { IWB } \\
\text { Used? / } \\
\text { How? }\end{array}$ & Who & $\begin{array}{l}\text { Description of } \\
\text { Activities }\end{array}$ \\
\hline & $\begin{array}{l}52: 27- \\
1: 13: 34\end{array}$ & $\begin{array}{l}\text { - letters of the } \\
\text { alphabet, letter } \\
\text { recognition, } \\
\text { letter formation }\end{array}$ & $\begin{array}{l}\text { Independent } \\
\text { Practice }\end{array}$ & $\begin{array}{l}\text { Yes - } \\
\text { Tactile } \\
\text { Interact } \\
(\mathrm{S})\end{array}$ & Students & $\begin{array}{l}\text { Students worked } \\
\text { at the IWB, at } \\
\text { times the teacher } \\
\text { helped them, but } \\
\text { it was mostly } \\
\text { independent. }\end{array}$ \\
\hline
\end{tabular}


Appendix 4: Lesson Summary Example Using Codes from Appendix 2

Sharon's Lesson (Grade 6 LA and Math) Excerpt

\begin{tabular}{|c|c|c|c|c|c|c|c|c|}
\hline \multirow[t]{2}{*}{ Duration } & \multirow[t]{2}{*}{ Time / Activity } & \multirow[t]{2}{*}{ Objective } & \multirow{2}{*}{$\begin{array}{l}\text { Instructional } \\
\text { Meth. } \\
\text { (Dewitz) }\end{array}$} & \multicolumn{2}{|c|}{ Whole Class Tech Use } & \multicolumn{2}{|c|}{ Individual Tech Use } & \multirow[t]{2}{*}{ Description of Activities } \\
\hline & & & & What / How & Who & $\begin{array}{l}\text { What / } \\
\text { How }\end{array}$ & Who & \\
\hline 2 & LESSON BEGINS & - & None & None & None & None & None & $\begin{array}{l}\text { Students enter class and get } \\
\text { ready for the day. "Teacher's } \\
\text { computer is 'fried' and needs } \\
\text { to do report cards }\end{array}$ \\
\hline 8 & Free Writing & $\begin{array}{l}\text { - Writing on a } \\
\text { topic of } \\
\text { interest }\end{array}$ & $\begin{array}{l}\text { Independent } \\
\text { Practice }\end{array}$ & $\begin{array}{l}\text { Computer w/ } \\
\text { Projector - in } \\
\text { use }\end{array}$ & $\begin{array}{l}\text { Display only } \\
\text { (intended - } \\
\text { technical } \\
\text { glitch up to } \\
\text { 10:00) }\end{array}$ & None & None & $\begin{array}{l}\text { Directions for activity are on } \\
\text { the board in marker. Writing } \\
\text { Journals - "I did mine in } \\
\text { word power". Teacher } \\
\text { crosses to laptop, will be } 10 \\
\text { minutes of writing. Turns on } \\
\text { projector on top of her } \\
\text { writing (marker) on the } \\
\text { whiteboard. Google is } \\
\text { forcing her to change her } \\
\text { password, so she instructs } \\
\text { students to use their } \\
\text { challenge words in sentences } \\
\text { while they wait. }\end{array}$ \\
\hline 1 & & - & $\begin{array}{l}\text { Independent } \\
\text { Practice }\end{array}$ & $\begin{array}{l}\text { Computer w/ } \\
\text { Projector - in } \\
\text { use }\end{array}$ & $\begin{array}{l}\text { None - } \\
\text { Display only } \\
* \text { see above } \\
\end{array}$ & None & None & $\begin{array}{l}\text { To me - "I can't put it up } \\
\text { with chrome book either, this } \\
\text { changes what we're doing" }\end{array}$ \\
\hline 4 & & - & $\begin{array}{l}\text { Independent } \\
\text { Practice }\end{array}$ & $\begin{array}{l}\text { Computer w/ } \\
\text { Projector }- \text { in } \\
\text { use }\end{array}$ & $\begin{array}{l}\text { None - } \\
\text { Display only } \\
* \text { see above }\end{array}$ & None & None & $\begin{array}{l}\text { Student is given permission } \\
\text { to use headphones if he } \\
\text { wants. Instructs students to } \\
\text { "Write whatever is in your } \\
\text { head" }\end{array}$ \\
\hline 4 & & - & $\begin{array}{l}\text { Independent } \\
\text { Practice }\end{array}$ & $\begin{array}{l}\text { Computer w/ } \\
\text { Projector - in } \\
\text { use }\end{array}$ & Display only & None & None & $\begin{array}{l}\text { T. turns projector back on } \\
\text { with the green slide - flips to } \\
\text { slide } 31 \text { that contains } \\
\text { "Backwards day, Trivial fact, } \\
\text { Quote by Hellen Keller, and }\end{array}$ \\
\hline
\end{tabular}




\begin{tabular}{|c|c|c|c|c|c|c|c|c|}
\hline \multirow[t]{2}{*}{ Duration } & \multirow[t]{2}{*}{ Time / Activity } & \multirow[t]{2}{*}{ Objective } & \multirow{2}{*}{$\begin{array}{l}\text { Instructional } \\
\text { Meth. } \\
\text { (Dewitz) }\end{array}$} & \multicolumn{2}{|c|}{ Whole Class Tech Use } & \multicolumn{2}{|c|}{ Individual Tech Use } & \multirow[t]{2}{*}{ Description of Activities } \\
\hline & & & & What / How & Who & $\begin{array}{l}\text { What / } \\
\text { How }\end{array}$ & Who & \\
\hline & & & & & & & & $\begin{array}{l}\text { a Vocabulary word for the } \\
\text { day" }\end{array}$ \\
\hline 1 & & - & $\begin{array}{l}\text { Independent } \\
\text { Practice }\end{array}$ & $\begin{array}{l}\text { Computer w/ } \\
\text { Projector - in } \\
\text { use }\end{array}$ & Display only & None & None & $\begin{array}{l}\text { Students to write the quote in } \\
\text { the back of their journals. On } \\
\text { Friday they will choose one } \\
\text { slide to respond to. Discusses } \\
\text { what quote means }\end{array}$ \\
\hline 3 & & - & $\begin{array}{l}\text { Independent } \\
\text { Practice }\end{array}$ & $\begin{array}{l}\text { Computer w/ } \\
\text { Projector }- \text { not in } \\
\text { use }\end{array}$ & None & None & None & $\begin{array}{l}\text { Students read their own } \\
\text { writing }\end{array}$ \\
\hline 2 & & - & $\begin{array}{l}\text { Independent } \\
\text { Practice }\end{array}$ & $\begin{array}{l}\text { Computer w/ } \\
\text { Projector - in } \\
\text { use }\end{array}$ & Display only & None & None & $\begin{array}{l}\text { Check that neighbours wrote } \\
\text { quote and initial it. Now } \\
\text { teacher computer is working } \\
\text { and students share something } \\
\text { they are thankful for. }\end{array}$ \\
\hline 2 & \multirow[t]{2}{*}{$\begin{array}{l}\text { Movement Break / } \\
\text { Teacher prep for } \\
\text { activity }\end{array}$} & - Spelling & $\begin{array}{l}\text { Independent } \\
\text { practice }\end{array}$ & CD Player & Teacher & None & None & $\begin{array}{l}\text { Students move around room, } \\
\text { find a partner, and name } \\
\text { something for which they are } \\
\text { thankful and practicing } \\
\text { spelling words }\end{array}$ \\
\hline 3 & & - Spelling & $\begin{array}{l}\text { Independent } \\
\text { Practice }\end{array}$ & $\begin{array}{l}\text { Computer w/ } \\
\text { Projector - in } \\
\text { use }\end{array}$ & Teacher & None & None & $\begin{array}{l}\text { Teacher erases board and } \\
\text { displays from projector - } \\
\text { papers and some writing. } \\
\text { Mathnavox (from } \\
\text { LearnAlberta site) = } \\
\text { Estimating Quantities. }\end{array}$ \\
\hline 2 & \multirow[t]{2}{*}{$\begin{array}{l}\text { Math-Decimal of } \\
\text { the Day sheet }\end{array}$} & $\begin{array}{l}\text { - Rounding } \\
\text { and place } \\
\text { value for } \\
\text { estimation }\end{array}$ & $\begin{array}{l}\text { Independent } \\
\text { Practice }\end{array}$ & $\begin{array}{l}\text { Computer w/ } \\
\text { Projector - in } \\
\text { use }\end{array}$ & Teacher & None & None & $\begin{array}{l}\text { Teacher clicks on an } \\
\text { estimating strategy, erases } \\
\text { quote from the board. Having } \\
\text { a concern, can't hear audio } \\
\text { for the math activity on } \\
\text { estimating jellybeans. } \\
\text { Displays an activity sheet, } \\
\text { hands out a "decimal of the } \\
\text { day" sheet. }\end{array}$ \\
\hline 6 & & $\begin{array}{l}\text { - Math place } \\
\text { value and }\end{array}$ & $\begin{array}{l}\text { Independent } \\
\text { Practice }\end{array}$ & $\begin{array}{l}\text { Computer w/ } \\
\text { Projector }- \text { in }\end{array}$ & Teacher & None & None & $\begin{array}{l}\text { Teacher switches to chrome } \\
\text { book. Access LearnAlberta }\end{array}$ \\
\hline
\end{tabular}




\begin{tabular}{|c|c|c|c|c|c|c|c|c|}
\hline \multirow[t]{2}{*}{ Duration } & \multirow[t]{2}{*}{ Time / Activity } & \multirow[t]{2}{*}{ Objective } & \multirow{2}{*}{$\begin{array}{l}\text { Instructional } \\
\text { Meth. } \\
\text { (Dewitz) }\end{array}$} & \multicolumn{2}{|c|}{ Whole Class Tech Use } & \multicolumn{2}{|c|}{ Individual Tech Use } & \multirow[t]{2}{*}{ Description of Activities } \\
\hline & & & & What / How & Who & $\begin{array}{l}\text { What / } \\
\text { How }\end{array}$ & Who & \\
\hline & & rounding & & use & & & & $\begin{array}{l}\text { website for Mathematics. } \\
\text { Reloads Mathnavox site, } \\
\text { checks their progress on } \\
\text { worksheet assessment. }\end{array}$ \\
\hline 2 & \multirow[t]{5}{*}{ BEDMAS work } & $\begin{array}{l}\text { - Math place } \\
\text { value and } \\
\text { rounding }\end{array}$ & $\begin{array}{l}\text { Independent } \\
\text { Practice }\end{array}$ & $\begin{array}{l}\text { Computer w/ } \\
\text { Projector - in } \\
\text { use }\end{array}$ & Teacher & None & None & $\begin{array}{l}\text { T: "Take out your BEDMAS } \\
\text { and work on it while waiting. } \\
\text { Use a calculator if you need } \\
\text { to. }\end{array}$ \\
\hline 2 & & $\begin{array}{l}\text { - Math place } \\
\text { value and } \\
\text { rounding }\end{array}$ & $\begin{array}{l}\text { Independent } \\
\text { Practice }\end{array}$ & $\begin{array}{l}\text { Computer w/ } \\
\text { Projector - in } \\
\text { use }\end{array}$ & Display only & Calculator & A few & $\begin{array}{l}\text { Many issues with the } \\
\text { rounding - use calculator to } \\
\text { check answers }\end{array}$ \\
\hline 3 & & $\begin{array}{l}\text { - Math place } \\
\text { value and } \\
\text { rounding }\end{array}$ & $\begin{array}{l}\text { Guided } \\
\text { practice }\end{array}$ & $\begin{array}{l}\text { Computer w/ } \\
\text { Projector - in } \\
\text { use }\end{array}$ & Teacher & None & None & $\begin{array}{l}\text { Rounding numbers page is } \\
\text { finally open on projector - } \\
\text { shouldn't there be a.... goes } \\
\text { back to restart animation. } \\
\text { Reads the instructions }\end{array}$ \\
\hline 10 & & $\begin{array}{l}\text { - Math place } \\
\text { value and } \\
\text { rounding }\end{array}$ & $\begin{array}{l}\text { Guided } \\
\text { practice }\end{array}$ & $\begin{array}{l}\text { Computer w/ } \\
\text { Projector - in } \\
\text { use }\end{array}$ & Display only & None & None & $\begin{array}{l}\text { Teacher writes a number on } \\
\text { the board, over top of the } \\
\text { projected image of place } \\
\text { values. }\end{array}$ \\
\hline 1 & & $\begin{array}{l}\text { - Math place } \\
\text { value and } \\
\text { rounding }\end{array}$ & $\begin{array}{l}\text { Guided } \\
\text { practice }\end{array}$ & $\begin{array}{l}\text { Computer w/ } \\
\text { Projector - in } \\
\text { use }\end{array}$ & Display only & None & None & $\begin{array}{l}\text { Students instructed to copy } \\
\text { from board. Teacher writes a } \\
\text { new number on the board for } \\
\text { them to do - round to } 10 \mathrm{~s} \\
100 \text { s etc. as exit ticket }\end{array}$ \\
\hline 5 & \multirow[t]{2}{*}{ Silent Reading } & $\begin{array}{l}\text { - Independent } \\
\text { reading }\end{array}$ & $\begin{array}{l}\text { Independent } \\
\text { Practice }\end{array}$ & None & None & None & None & $\begin{array}{l}\text { Teacher checks students' } \\
\text { work before recess. Students } \\
\text { to read until recess. }\end{array}$ \\
\hline 4 & & $\begin{array}{l}\text { - Independent } \\
\text { reading }\end{array}$ & $\begin{array}{l}\text { Independent } \\
\text { Practice }\end{array}$ & None & None & None & None & $\begin{array}{l}\text { Teacher erases the numbers } \\
\text { she's written on the board }\end{array}$ \\
\hline & DISMISSAL & - & & & & & & \\
\hline
\end{tabular}

